\title{
Induced pluripotent stem (iPS) cells: an up-to-the-minute review Frank Lau ${ }^{1}$, Tim Ahfeldt ${ }^{1}$, Kenji Osafune ${ }^{2,3}$, Hidenori Akustsu ${ }^{4}$ and Chad A Cowan ${ }^{1 *}$
}

\begin{abstract}
Addresses: ${ }^{1}$ Stowers Medical Institute and Harvard Stem Cell Institute, Harvard University, Department of Stem Cell and Regenerative Biology, 185 Cambridge Street CPZN 4234, Boston, MA 02114, USA; ${ }^{2}$ Center for iPS Cell Research and Application (CiRA), Institute for Integrated Cell-Material Sciences (iCeMS), Kyoto University, 53 Kawahara-cho, Shogoin, Sakyo-ku, Kyoto 606-8507, Japan; ${ }^{3}$ PRESTO, Yamanaka iPS Cell Special Project, Japan Science and Technology Agency (JST), 4-1-8 Honcho, Kawaguchi, Saitama 332-0012, Japan; ${ }^{4}$ National Research Institute for Child Health and Development, Department of Reproductive Biology, 2-10-1 Okura, Setagaya-ku, Tokyo 157-8535, Japan

*Corresponding author: Chad A Cowan (ccowan1@partners.org)

Fl000 Biology Reports 2009, 1:84 (doi:10.34I0/BI-84)

The electronic version of this article is the complete one and can be found at: http://FI000.com/Reports/Biology/content/I/84

Abstract

Recent advances in nuclear reprogramming technology allow the transformation of terminally differentiated, adult cells into induced pluripotent stem cells whose phenotype is indistinguishable from that of embryonic stem cells. This leap forward enables the creation of patient-specific pluripotent cell lines that carry disease genotypes. These cell lines could be used both as in vitro models for the study of disease and as potential sources of material for cell replacement therapy. Ultimately, a greater understanding of the process by which cellular identity is shaped and altered may allow the generation of particular cell types for the treatment of degenerative disease.
\end{abstract}

\section{Introduction and context}

Development involves two distinct cellular processes: division and differentiation. Division is the means by which one cell gives rise to two daughter cells and is indispensable for the growth of an organism and the renewal of fully developed tissues. Differentiation refers to the process by which a cell specializes to perform a particular biological function in an adult. Differentiation usually occurs through a combination of cell-cell interactions, exposure to diffusible factors, and other positional cues that ultimately alter gene expression, conferring a specific cellular identity and function.

One of the more remarkable observations in the past century is that differentiation is not a unidirectional process. Instead, it can be turned back much like the hands of a clock. This rewinding of the developmental clock is termed nuclear reprogramming and is often defined as the process whereby an adult somatic nucleus has developmental potential restored to it [1]. There are three ways that nuclear reprogramming has been accomplished: (a) somatic cell nuclear transfer or cloning, (b) cell fusion, and (c) factor-based reprogramming to produce induced pluripotent stem (iPS) cells. Here, we will discuss each approach with special emphasis on the most recent advances in this field and the challenges that lie ahead.

Somatic cell nuclear transfer, a procedure in which the nucleus of an adult cell is injected into an unfertilized egg whose chromosomes have been removed, has demonstrated that the genome of adult cells can be reset to an embryonic state [2,3]. Using this strategy, researchers have generated cloned embryos that possess the potential to develop into an adult animal or become an embryonic stem cell (ESC) line that is genetically identical to that of the donor nucleus $[4,5]$. These experiments established that no irreversible changes are made to the genome during development and further showed that animal oocytes harbored factors that could accomplish nuclear reprogramming.

In a related series of experiments, a number of researchers have shown that when somatic cells are 
fused with ESCs, the resulting tetraploid hybrid cells silence the expression of somatic genes and establish a program of transcription indistinguishable from ESCs, indicating that ESCs contain the necessary reprogramming activities to accomplish this transformation [6,7]. Thus, the cytoplasm of the enucleated oocyte and the ESC is able to re-establish the pluripotent state via a mechanism dependent on global epigenetic and transcriptional changes.

The mechanism by which this transformation occurred and the mediators of nuclear reprogramming were largely undefined. In a breakthrough experiment, Takahashi and Yamanaka [8] identified four factors normally found in ESCs - Oct3/4, Sox2, Klf4, and c-Myc (OSKM)that were sufficient to reprogram mouse somatic cells to closely resemble mouse ESCs. They called these iPS cells. Since this first report, the technique has been rapidly confirmed, improved, and subsequently applied to successfully reprogram somatic cells. This technology has since given birth to an entire field that has grown at a phenomenal pace.

\section{Major recent advances}

The rate at which iPS lines are being created is rapidly increasing. Although most iPS cells have been created from fibroblasts, in the past two years lines have also been created from adult neural stem cells [9], keratinocytes [10], hematopoietic somatic cells [11-13], fetal cells harvested during both amniotic fluid and chorionic villus sampling, and several other somatic cell types [11]. It appears that reprogramming is possible in almost any cell type, although the efficiency of the reprogramming process varies between cell types. Finding the best somatic cell types to accomplish reprogramming remains a main challenge for iPS cell research; we will discuss this in greater detail later on. Significant progress has been made in the next natural step after iPS cell creation: redifferentiating iPS cells into somatic cells. iPS cells have been re-differentiated into several somatic tissues, including active motor neurons [14], insulin-secreting islet-like clusters [15], and a number of cardiovascular cells (arterial endothelium, venous endothelium, lymphatic endothelium, and cardiomyocytes) $[16,17]$.

\section{Disease modeling with iPS cells}

Currently, there are two major questions addressed by iPS cell research. One seeks to produce iPS cell lines that capture the genotypes of disease. These cell lines would offer an unprecedented opportunity to understand pathobiology, identify abnormalities in the development or function of differentiated cells affected by disease, develop therapies that render these cells resistant to disease, and provide sources of material for cell replacement therapy. Ultimately, the goal is to develop new therapies in which treatment is either non-existent or insufficient.

Numerous groups have reported the creation of diseasespecific iPS lines. A group headed by Kevin Eggan [18] has generated iPS cells from patient fibroblasts of a familial form of amyotrophic lateral sclerosis. Another group, headed by George Daley [19], has produced iPS cells from patients with 10 different genetic diseases, including Parkinson's disease, type-1 diabetes, Duchenne and Becker muscular dystrophy, adenosine deaminase deficiency-related severe combined immunodeficiency, Shwachman-Bodian-Diamond syndrome, Gaucher's disease type III, Huntington's disease, Down's syndrome, and the carrier state of Lesch-Nyhan syndrome. Groups led by Svendsen [20] and Jaenisch [21] have added to the list of disease-specific iPS cells by creating human cell-based models of spinal muscular atrophy and Parkinson's disease, respectively.

More recently, the Kan group [11] created iPS cells from skin fibroblasts of a patient with homozygous betathalassemia and subsequently differentiated them into hemoglobin-producing hematopoietic cells. In theory, these cells could be treated with gene therapy to yield autologous hematopoietic cells that function normally. The Belmonte group [22] advanced this goal when they derived iPS cells from dermal fibroblasts harvested from Fanconi anemia patients, corrected the genetic defect using lentiviral vectors encoding for FANCA and FANCD2, and subsequently derived somatic cells that were phenotypically disease-free.

In a publication demonstrating the broad utility of disease-specific iPS cells, the Studer group [23] generated iPS cells from patients with familial dysautonomia (FD), re-differentiated the iPS cells into cells of all three germ layers, and demonstrated tissue-specific mis-splicing of the protein responsible for FD. During redifferentiation, they also gained novel insights into the pathogenesis of FD: they demonstrated a possible mechanism for the tissue specificity of FD and uncovered defects in cell differentiation and migration. Lastly, they successfully used their in vitro model to screen candidate drugs.

\section{Mechanistic understanding}

The second major question in iPS cell research seeks to define the underlying mechanism by which nuclear reprogramming is accomplished. This includes identifying the molecular players, the key cellular and molecular events, and the likely ways in which this process might fail. The goal is to make the iPS induction process safer and more efficient and to one day manipulate the 
underlying cellular state of any cell, thereby generating specific cell types at will.

The nature of the factors required for the reprogramming of somatic cells into iPS cells has been elucidated. In particular, Oct4 has emerged as a central molecule in iPS cell reprogramming; for example, neural stem cells can be reprogrammed to iPS cells with Oct4 alone, which was not unexpected as they express high levels of endogenous Sox2 [9]. To date, no cell line has been reprogrammed without Oct4. While Yamanaka's original four-factor combination remains the most widely used, several other combinations have been shown to generate iPS cells. Two of the earliest alternative combinations were developed by the Thompson group [24]. They successfully used Oct4/Sox $/ \mathrm{Nanog} / \mathrm{Klf} 4$ as well as as Oct $4 / \operatorname{Sox} 2 / \mathrm{Nanog} / \mathrm{Lin} 28$ to create iPS cell lines. Recently, the $\mathrm{Ng}$ group [25] was able to reprogram mouse embryonic fibroblasts (MEFs) by using Esrrb, which is an orphan nuclear receptor, in combination with Oct4, Sox2, and c-Myc.

It has also been shown that some of the reprogramming factors can be replaced with chemicals. The Melton group [26] added valproic acid to newborn human skin (fibroblast) cells in culture and was able to create iPS cells with only two reprogramming factors, Oct 4 and Sox2, eliminating the need for two potent cancerpromoting genes, $c-M y c$ and Klf4. The Ding group [27] used a combination of the small molecules BIX-01294 and BayK8644 to generate iPS from MEFs that were transfected with only Oct 4 and Klf4. The promise of these approaches is to create iPS cells by using chemicals alone.

\section{Improving induction}

Several groups have recently developed several alternative iPS cell production methods. The iPS cells produced in each new method appear to be very similar to those produced in the traditional method. Each new method has its own advantages and disadvantages as compared with the original method, and each provides insight into how scientists may be able to develop iPS cells that are safe for use in clinical trials.

Hochedlinger and colleagues [28] used adenoviruses to deliver reprogramming factors into adult mouse liver cells. Newborn mouse fibroblasts were also transduced; however, these were transgenic and required doxycycline induction of Oct4 expression for iPS generation. Very recently, the Freed group [29] established three human iPS lines from fibroblasts by using adenoviruses. The adenoviral approach is advantageous because it avoids integrating exogenous genes into the genome and the potential for insertional mutagenesis. The virus needs to be present for only a short time in order to accomplish reprogramming. However, the technique is inefficient compared with iPS transduction with retroviruses and still uses cancer-promoting genes, and the adenovirus may still integrate into the host DNA at low frequencies.

Yamanaka's group [30] reported success at generating murine iPS cells without using any viruses. They successfully reprogrammed mouse cells by transfection with two plasmid constructs carrying the reprogramming factors; the first plasmid expressed c-Myc while a second, polycistronic plasmid expressed Oct4, Klf4, and Sox2. In a related approach, the Belmonte group [31] used one polycistronic construct expressing all four factors to achieve nucleofection in MEFs and induced iPS formation. These methods avoid viruses entirely but still require cancer-promoting genes to accomplish reprogramming. As with the adenoviral strategies, plasmidbased approaches are much less efficient compared with retroviral methods and begin with embryonic skin cells, which may be more amenable to reprogramming than adult skin cells. Moreover, transfected plasmids have been shown to integrate into the host genome and therefore pose a risk of insertional mutagenesis [32].

Three separate research groups addressed the low efficiency of non-retroviral approaches to iPS induction by using the piggyBac transposon system to deliver the OSKM reprogramming factors to MEFs [33-35]. piggyBac is unusual among transposon systems because upon reexcision of the exogenous genes, no 'footprint' mutations are left in the host cell genome.

The Jaenisch group [21] reprogrammed fibroblasts from Parkinson's disease patients by using floxed doxycyclineinducible lentiviral vectors that can be excised using Cre recombinase. While this strategy yielded human iPS cells with global transcriptomes that more closely resembled those of human ESCs, a genomic 'footprint' (the loxP site) was left behind, so the mutagenicity of the retroviral approaches remains.

The Thomson group [36] recently used the episomal vector oriP/EBNA1 to generate iPS cells from human foreskin fibroblasts. This vector is duplicated as an extrachromosomal episome once per cell cycle and is stable as long as drug selection is used. In the absence of drug selection, the episomal vector is lost at a rate of 5\% per iPS generation. After a few generations, iPS cells that do not carry the vector can be isolated. The major disadvantage to this approach is its low efficiency. 
The Ding group [37] recently reported iPS cell generation using recombinant proteins. The protein reprogramming factors were delivered into MEFs by conjugating the proteins to poly-arginine, a short peptide that mediates protein transduction. A parallel approach was shown to work in human fibroblasts by the Kim group [38], who fused the OSKM factors to cell-penetrating peptide sequences. The major advantage to these protein-based strategies is that exogenous genes are not introduced. However, the strategy is again rather inefficient.

\section{Increasing efficiency}

The efficiency of reprogramming adult fibroblasts remains low $(<0.1 \%)$. Whether this frequency reflects the need for the precise timing, balance, and absolute levels of expression of the reprogramming genes or selection for rare genetic/epigenetic changes either initially present in the somatic cell population or acquired during prolonged culture remains unsolved. Although considerable advances have been made in identifying the complex networks involved, we do not yet understand how these factors maintain pluripotency, how growth factors control and stabilize these networks, or how these cells respond so precisely to differentiation cues. Certain small molecules, including valproic acid (a histone deacetylase inhibitor) [39], 5-aza-cytidine [40], and BIX01294 [41], seem to improve the efficiency of the iPS cell generation process. We expect that more chemicals that improve the efficiency of iPS cell reprogramming will be identified. Ultimately, the goal is to develop a cocktail of reprogramming factors which efficiently and reliably transduces somatic cells to iPS cells.

Most recently, attention has focused on p53 as a key player in the efficiency of iPS cell transduction. In 2008, the Deng group [42] demonstrated that adding p53 siRNA (small interfering RNA) to the OSKM reprogramming factors increased the rate of iPS cell colony formation by up to 100-fold. However, many of the resulting iPS cells were only partially reprogrammed, and none yielded teratomas in vivo.

The central role of p53 in controlling iPS cell transduction has been better defined in several newly published papers. The Yamanaka group [43] showed that in homozygous p53 knockout MEFs, $10 \%$ of the cells could be transduced to iPS cells with three reprogramming factors (Oct4/Sox2/Klf4). They further showed that terminally differentiated, p53 null T cells could be turned into iPS cells. The Belmonte group [44] arrived at similar conclusions when they infected cells with p53 shRNA (small hairpin RNA) and when they transduced $\mathrm{p} 53^{+/-}$ and $\mathrm{p} 53^{-/-}$MEFs into iPS cells. They further showed that reducing p21 and Bax levels, two factors downstream of p53, also increased the efficiency of iPS cell transduction. Two separate groups, led by Serrano [45] and Hochedlinger [46], focused on the Ink4/Arf locus, which is responsible for inhibiting $\mathrm{Mdm} 2$, which in turn is the main destabilizing enzyme of p53. The Serrano group found that downregulating tumor suppressors contained in the Ink4/Arf locus increased the efficiency of iPS cell transduction. The Hochedlinger group showed that cells with low endogenous Ink4a/Arf locus products are more readily reprogrammed into iPS cells and that genetic ablation of p53 converts non-reprogrammable somatic cells into cells that could be transduced to iPS cells. Lastly, the Blasco group [47] showed that p53 is responsible for preventing iPS cell transduction of G3 $\mathrm{Terc}^{-/-}$MEFs, which are cells with short telomeres. Taken together, these data show that the molecular network surrounding p53 strongly inhibits iPS cell transduction and that the disruption of this network increases the efficiency of iPS cell generation many-fold.

While the precise molecular mechanisms behind p53 inhibition of iPS cell reprogramming are unknown, a newly published study suggests that the very process of reprogramming upregulates tumor suppressor expression. The Gil group [48] found that the OSKM reprogramming factors induced DNA damage and chromatin remodeling, thereby resulting in the development of senescence characteristics, including expression of p16, p21, and p53.

\section{More animal models}

The creation of iPS lines from cells of species other than humans or mice expands the research potential of iPS in additional animal models. The Deng group [49] generated iPS cells from adult rhesus monkey fibroblasts. Two separate groups, one led by Ding [50] and the other by Xiao [51], created iPS cells from adult rat cells.

Most recently, iPS cells have been derived from somatic pig cells. The Xiao group [52] used tetracycline-inducible human Oct4/Sox2/Klf4/c-Myc/Nanog/Lin28 delivered via lentiviruses to transduce primary pig ear fibroblasts and primary bone marrow cells into iPS cells. The Roberts group [53] transduced porcine fetal fibroblasts into iPS cells by using human OSKM delivered with lentiviruses. The availability of model animal iPS cells offers a new and potentially powerful model for therapeutics.

\section{Complete pluripotency}

Previously, iPS cells had not been shown to contribute fully to all of the cell types in adult organisms. In a significant breakthrough, three separate groups (led by 
Zhou [54], Baldwin [55], and Gao [56]) recently reported that, in mice, MEF-derived iPS cells could be injected into tetraploid blastocysts and result in the live birth of mice derived entirely from iPS cells. Different iPS lines were, to varying degrees, effective at producing viable offspring, with some lines showing early termination of fetal development. The success of this approach seems related to the age of the somatic cells from which the iPS cells were derived. With these reports, the debate over the equivalence of ESCs and iPS with regard to pluripotency has been resolved, at least in mice.

\section{Future directions}

In the rapidly developing field of iPS cell research, we expect to see improved and more efficient iPS derivation protocols in the near future. The key will be the development of methods that do not rely on the integration of the transgenes but that are still highly efficient. As shown by the recent tetraploid complementation studies, the age at which somatic cells are harvested plays a key role in the derived iPS cells' pluripotency. As such, it will be important to identify somatic cell types that are easily harvested and that harbor the fewest mutations. It might be advisable to collect cord blood from newborns as they have been shown to be candidates for reprogramming and would at that time harbor very few mutations.

We are only beginning to understand the mechanism and kinetics of iPS cell reprogramming. Elucidation of these would overcome the current problems of low frequency and inefficient iPS cell transduction. An integrative genomic analysis of the reprogramming process demonstrated that the repression of lineagespecific transcription factors and DNA de-methylation are critical and inefficient steps [40].

Several reviews have addressed the question of quality standards for iPS cells $[57,58]$. A minimum set of criteria for iPS characterization includes: (a) pluripotent stem cell morphology and unlimited self-renewal, (b) expression of pluripotency markers and downregulation of differentiation markers, (c) reprogramming factor independence, and (d) 'proof of functional differentiation through the highest-stringency test acceptable' [58].

The promise of iPS cells includes applications in both patient care and advanced cellular research. Currently, incomplete silencing of viral transgenes and even continued dependence on exogenous factors to maintain pluripotency are barriers to fulfilling the promise of iPS cells.

It has also been shown that significant differences in the differentiation potential of different human ESC lines exist, even though the observable differences in the pluripotent state are marginal [59]. Thus, although the demonstration of complete iPS cell pluripotency via the tetraploid complementation studies was significant, it remains necessary to develop and standardize differentiation protocols that assess the potential of iPS lines.

While the transcriptional and genomic characterizations of iPS cells are somewhat established, no proteomic characterization has been performed. The recent discovery of microRNAs (miRNAs) presents another area of potential research and characterization; the $\mathrm{Wu}$ group [60] at Stanford University performed the first 'miRNAome' analysis of human iPS cells compared with human ESCs and fibroblasts.

\section{Conclusions}

In a short period of time, iPS cells have proven to be a major new frontier for biologic research. iPS cells have been created in humans and several animal models, including mice, rats, pigs, and primates. They have been generated from numerous somatic cell types, and disease-specific iPS cells have been created from dozens of diseases. Most recently, iPS cells have been shown to autonomously develop into full-term mice via tetraploid complementation. Over the coming months and years, improved iPS cell generation efficiency and iPS cellbased disease modeling and drug discovery will yield new discoveries, culminating in the development of low-cost, patient-specific, cell-based therapies.

\section{Abbreviations}

ESC, embryonic stem cell; FD, familial dysautonomia; iPS, induced pluripotent stem; MEF, mouse embryonic fibroblast; miRNA, microRNA; OSKM, Oct4/Sox2/Klf4/ c-Myc; shRNA, small hairpin RNA; siRNA, small interfering RNA.

\section{Competing interests}

The authors declare that they have no competing interests.

\section{References}

I. Rodolfa K, Di Giorgio FP, Sullivan S: Defined reprogramming: a vehicle for changing the differentiated state. Differentiation 2007, 75:577-9.

2. Wilmut I, Beaujean N, de Sousa PA, Dinnyes A, King T], Paterson LA, Wells DN, Young LE: Somatic cell nuclear transfer. Nature 2002, 419:583-6.

3. Egli D, Rosains J, Birkhoff G, Eggan K: Developmental reprogramming after chromosome transfer into mitotic mouse zygotes. Nature 2007, 447:679-85.

FI000 Factor 6.0 Must Read

Evaluated by Ali H Brivanlou 26 Jun 2007

4. Rodolfa $\mathrm{KT}$, Eggan $\mathrm{K}$ : A transcriptional logic for nuclear reprogramming. Cell 2006, I 26:652-5. 
5. Markoulaki S, Meissner A, Jaenisch R: Somatic cell nuclear transfer and derivation of embryonic stem cells in the mouse. Methods 2008, 45:101-14.

6. Cowan CA, Atienza J, Melton DA, Eggan K: Nuclear reprogramming of somatic cells after fusion with human embryonic stem cells. Science 2005, 309:1369-73.

7. Tada M, Takahama Y, Abe K, Nakatsuji N, Tada T: Nuclear reprogramming of somatic cells by in vitro hybridization with ES cells. Curr Biol 200I, I I:I553-8.

8. Takahashi K, Yamanaka S: Induction of pluripotent stem cells from mouse embryonic and adult fibroblast cultures by defined factors. Cell 2006, I 26:663-76.

FI000 Factor 10.5 Exceptional

Evaluated by Charles Brenner II Jun 2007, Thomas Graf 30 Aug 2006, Wolf Reik 04 Sep 2006, Raphael Kopan 12 Sep 2006, Charles Coutelle 24 Oct 2006

9. Kim JB, Sebastiano V, Wu G, Araúzo-Bravo MJ, Sasse P, Gentile L, Ko K, Ruau D, Ehrich M, van den Boom D, Meyer J, Hübner K, Bernemann C, Ortmeier C, Zenke M, Fleischmann BK, Zaehres H, Schöler HR: Oct4-induced pluripotency in adult neural stem cells. Cell 2009, I36:4II-9.

FI000 Factor 6.0 Must Read

Evaluated by Eric Schulze-Bahr 3I Mar 2009

10. Aasen T, Raya A, Barrero MJ, Garreta E, Consiglio A, Gonzalez F, Vassena R, Bilić J, Pekarik V, Tiscornia G, Edel M, Boué S, Izpisúa Belmonte JC: Efficient and rapid generation of induced pluripotent stem cells from human keratinocytes. Nat Biotechnol 2008, 26:1276-84.

II. Ye L, Chang JC, Lin C, Sun X, Yu J, Kan YW: Induced pluripotent stem cells offer new approach to therapy in thalassemia and sickle cell anemia and option in prenatal diagnosis in genetic diseases. Proc Natl Acad Sci U S A 2009, 106:9826-30.

FI000 Factor 6.0 Must Read

Evaluated by Valder Arruda 09 Jul 2009

12. Loh YH, Agarwal S, Park IH, Urbach A, Huo H, Heffner GC, Kim K, Miller JD, Ng K, Daley GQ: Generation of induced pluripotent stem cells from human blood. Blood 2009, I I3:5476-9.

FI000 Factor 4.8 Must Read

Evaluated by James Ellis 0 I April 2009, Anthony D Ho 0 I Jun 2009

13. Pereira CF, Terranova R, Ryan NK, Santos J, Morris KJ, Cui W, Merkenschlager M, Fisher AG: Heterokaryon-based reprogramming of human B lymphocytes for pluripotency requires Oct4 but not Sox2. PLoS Genet 2008, 4:e1000I70.

14. Karumbayaram S, Novitch BG, Patterson M, Umbach JA, Richter L, Lindgren A, Conway AE, Clark AT, Goldman SA, Plath K, WiedauPazos M, Kornblum HI, Lowry WE: Directed differentiation of human-induced pluripotent stem cells generates active motor neurons. Stem Cells 2009, 27:806-II.

15. Tateishi K, He J, Taranova O, Liang G, D'Alessio AC, Zhang Y: Generation of insulin-secreting islet-like clusters from human skin fibroblasts. J Biol Chem 2008, 283:3160I-7.

16. Taura D, Sone M, Homma K, Oyamada N, Takahashi K, Tamura N, Yamanaka S, Nakao K: Induction and isolation of vascular cells from human induced pluripotent stem cells-brief report. Arterioscler Thromb Vasc Biol 2009, 29: I 100-3.

17. Narazaki G, Uosaki H, Teranishi M, Okita K, Kim B, Matsuoka S, Yamanaka S, Yamashita JK: Directed and systematic differentiation of cardiovascular cells from mouse induced pluripotent stem cells. Circulation 2008, I I 8:498-506.

18. Dimos JT, Rodolfa KT, Niakan KK, Weisenthal LM, Mitsumoto $H$, Chung W, Croft GF, Saphier G, Leibel R, Goland R, Wichterle H, Henderson CE, Eggan K: Induced pluripotent stem cells generated from patients with ALS can be differentiated into motor neurons. Science 2008, 321:1218-21.

FI000 Factor 3.0 Recommended

Evaluated by Ulf Pettersson II Sep 2008
19. Park IH, Arora N, Huo H, Maherali N, Ahfeldt T, Shimamura A, Lensch MW, Cowan C, Hochedlinger K, Daley GQ: Disease-specific induced pluripotent stem cells. Cell 2008, 134:877-86.

FI000 Factor 9.0 Exceptional

Evaluated by Lois Weisman 19 Aug 2008

20. Ebert AD, Yu J, Rose FF Jr, Mattis VB, Lorson CL, Thomson JA, Svendsen $\mathrm{CN}$ : Induced pluripotent stem cells from a spinal muscular atrophy patient. Nature 2009, 457:277-80.

FI000 Factor 9.0 Exceptional

Evaluated by Steven Dowdy 30 Jan 2009

21. Soldner F, Hockemeyer D, Beard C, Gao Q, Bell GW, Cook EG, Hargus G, Blak A, Cooper O, Mitalipova M, Isacson O, Jaenisch R: Parkinson's disease patient-derived induced pluripotent stem cells free of viral reprogramming factors. Cell 2009, 136:964-77.

FI000 Factor 3.0 Recommended

Evaluated by John Mullins 2I April 2009

22. Raya A, Rodríguez-Pizà I, Guenechea G, Vassena R, Navarro S, Barrero MJ, Consiglio A, Castellà M, Río P, Sleep E, González F, Tiscornia G, Garreta E, Aasen T, Veiga A, Verma IM, Surrallés J, Bueren J, Izpisúa Belmonte JC: Disease-corrected haematopoietic progenitors from Fanconi anaemia induced pluripotent stem cells. Nature 2009, 460:53-9.

FI000 Factor 9.8 Exceptional

Evaluated by James Ellis 15 Jun 2009, Laura Haneline 25 Jun 2009, Michel Sadelain 07 Sep 2009

23. Lee G, Papapetrou EP, Kim H, Chambers SM, Tomishima MJ, Fasano CA, Ganat YM, Menon J, Shimizu F, Viale A, Tabar V, Sadelain M, Studer L: Modelling pathogenesis and treatment of familial dysautonomia using patient-specific iPSCs. Nature 2009, 46 I:402-6.

FI000 Factor 6.0 Must Read

Evaluated by Chaya Kalcheim 24 Aug 2009

24. Yu J, Vodyanik MA, Smuga-Otto K, Antosiewicz-Bourget J, Frane JL, Tian S, Nie J, Jonsdottir GA, Ruotti V, Stewart R, Slukvin II, Thomson JA: Induced pluripotent stem cell lines derived from human somatic cells. Science 2007, 318:1917-20.

FI000 Factor 9.0 Exceptional

Evaluated by Cheng-Ming Chiang 30 Nov 2007

25. Feng B, Jiang J, Kraus P, Ng JH, Heng JC, Chan YS, Yaw LP, Zhang W, Loh YH, Han J, Vega VB, Cacheux-Rataboul V, Lim B, Lufkin T, Ng HH: Reprogramming of fibroblasts into induced pluripotent stem cells with orphan nuclear receptor Esrrb. Nat Cell Biol 2009, I I:197-203.

FI000 Factor 3.0 Recommended

Evaluated by Patrick Tam 22 Jan 2009

26. Huangfu D, Osafune K, Maehr R, Guo W, Eijkelenboom A, Chen S, Muhlestein W, Melton DA: Induction of pluripotent stem cells from primary human fibroblasts with only Oct4 and Sox2. Nat Biotechnol 2008, 26:1269-75.

FI000 Factor 9.0 Exceptional

Evaluated by Jozef Lazar 17 Oct 2008

27. Shi Y, Desponts C, Do JT, Hahm HS, Schöler HR, Ding S: Induction of pluripotent stem cells from mouse embryonic fibroblasts by Oct4 and KIf4 with small-molecule compounds. Cell Stem Cell 2008, 3:568-74.

28. Stadtfeld M, Nagaya M, Utikal J, Weir G, Hochedlinger K: Induced pluripotent stem cells generated without viral integration. Science 2008, 322:945-9.

FI000 Factor 6.0 Must Read

Evaluated by Lorenz Studer 07 Oct 2008

29. Zhou W, Freed CR: Adenoviral gene delivery can reprogram human fibroblasts to induced pluripotent stem cells. Stem Cells 2009, [Epub ahead of print]. 
30. Okita K, Nakagawa M, Hyenjong $H$, Ichisaka T, Yamanaka S: Generation of mouse induced pluripotent stem cells without viral vectors. Science 2008, 322:949-53.

31. Gonzalez F, Barragan Monasterio M, Tiscornia G, Montserrat Pulido N, Vassena R, Batlle Morera L, Rodriguez Piza I, Izpisua Belmonte JC: Generation of mouse-induced pluripotent stem cells by transient expression of a single nonviral polycistronic vector. Proc Nat Acad Sci U S A 2009, 106:8918-22.

32. Murnane JP, Yezzi MJ, Young BR: Recombination events during integration of transfected DNA into normal human cells. Nucleic Acids Res 1990, 18:2733-8.

33. Yusa K, Rad R, Takeda J, Bradley A: Generation of transgene-free induced pluripotent mouse stem cells by the piggyBac transposon. Nat Methods 2009, 6:363-9.

34. Woltjen K, Michael IP, Mohseni P, Desai R, Mileikovsky M, Hämäläinen R, Cowling R, Wang W, Liu P, Gertsenstein M, Kaji K, Sung HK, Nagy A: piggyBac transposition reprograms fibroblasts to induced pluripotent stem cells. Nature 2009, 458:766-70.

FI000 Factor 9.0 Exceptional

Evaluated by M Angela Nieto 12 May 2009

35. Kaji K, Norrby K, Paca A, Mileikovsky M, Mohseni P, Woltjen K: Virus-free induction of pluripotency and subsequent excision of reprogramming factors. Nature 2009, 458:77I-5.

FI000 Factor 6.4 Must Read

Evaluated by Yi Eve Sun OI Apr 2009, M Angela Nieto 12 May 2009

36. Yu J, Hu K, Smuga-Otto K, Tian S, Stewart R, Slukvin II, Thomson JA: Human induced pluripotent stem cells free of vector and transgene sequences. Science 2009, 324:797-80I.

FI000 Factor 8.0 Exceptiona

Evaluated by Bill Lowry 06 Apr 2009, M Angela Nieto 12 May 2009

37. Zhou H, Wu S, Joo JY, Zhu S, Han DW, Lin T, Trauger S, Bien G, Yao S, Zhu Y, Siuzdak G, Schöler HR, Duan L, Ding S: Generation of induced pluripotent stem cells using recombinant proteins. Cell Stem Cell 2009, 4:38I-4.

FI000 Factor 8.I Exceptiona

Evaluated by William H Colledge 08 May 2009, David States 19 May 2009, Jason Yuan 22 Jul 2009

38. Kim D, Kim CH, Moon Jl, Chung YG, Chang MY, Han BS, Ko S, Yang E, Cha KY, Lanza R, Kim KS: Generation of human induced pluripotent stem cells by direct delivery of reprogramming proteins. Cell Stem Cell 2009, 4:472-6.

39. Feng $\mathrm{B}, \mathrm{Ng} \mathrm{JH}$, Heng $\mathrm{JC}, \mathrm{Ng} \mathrm{HH}$ : Molecules that promote or enhance reprogramming of somatic cells to induced pluripotent stem cells. Cell Stem Cell 2009, 4:30I-I2.

40. Mikkelsen TS, Hanna J, Zhang X, Ku M, Wernig M, Schorderet P, Bernstein BE, Jaenisch R, Lander ES, Meissner A: Dissecting direct reprogramming through integrative genomic analysis. Nature 2008, 454:49-55.

FI000 Factor 3.0 Recommended

Evaluated by Stephan Beck 23 Jun 2008

41. Shi Y, Do JT, Desponts C, Hahm HS, Schöler HR, Ding S: A combined chemical and genetic approach for the generation of induced pluripotent stem cells. Cell Stem Cell 2008, 2:525-8.

42. Zhao $Y$, Yin $X$, Qin $H$, Zhu F, Liu H, Yang $W$, Zhang Q, Xiang C, Hou P, Song Z, Liu Y, Yong J, Zhang P, Cai J, Liu M, Li H, Li Y, Qu X, Cui K, Zhang W, Xiang T, Wu Y, Zhao Y, Liu C, Yu C, Yuan K, Lou J, Ding $M$, Deng $\mathrm{H}$ : Two supporting factors greatly improve the efficiency of human iPSC generation. Cell Stem Cell 2008, 3:475-9.

43. Hong $H$, Takahashi K, Ichisaka T, Aoi T, Kanagawa O, Nakagawa M, Okita K, Yamanaka S: Suppression of induced pluripotent stem cell generation by the p53-p2 I pathway. Nature 2009, 460: I | $32-5$.
44. Kawamura T, Suzuki J, Wang YV, Menendez S, Morera LB, Raya A, Wahl GM, Belmonte JC: Linking the p53 tumour suppressor pathway to somatic cell reprogramming. Nature 2009, 460: $1140-4$.

45. Li H, Collado M, Villasante A, Strati K, Ortega S, Cañamero M, Blasco MA, Serrano M: The Ink4/Arf locus is a barrier for iPS cell reprogramming. Nature 2009, 460: I I36-9.

46. Utikal J, Polo JM, Stadtfeld M, Maherali N, Kulalert W, Walsh RM, Khalil A, Rheinwald JG, Hochedlinger K: Immortalization eliminates a roadblock during cellular reprogramming into iPS cells. Nature 2009, 460: I |45-8.

47. Marión RM, Strati K, Li H, Murga M, Blanco R, Ortega S, FernandezCapetillo O, Serrano M, Blasco MA: A p53-mediated DNA damage response limits reprogramming to ensure iPS cell genomic integrity. Nature 2009, 460: I 149-53.

48. Banito A, Rashid ST, Acosta JC, Li S, Pereira CF, Geti I, Pinho S, Silva JC, Azuara V, Walsh M, Vallier L, Gil J: Senescence impairs successful reprogramming to pluripotent stem cells. Genes Dev 2009, 23:2134-9.

49. Liu H, Zhu F, Yong J, Zhang $P$, Hou $P$, Li H, Jiang W, Cai J, Liu M, Cui K, Qu X, Xiang T, Lu D, Chi X, Gao G, Ji W, Ding M, Deng H: Generation of induced pluripotent stem cells from adult rhesus monkey fibroblasts. Cell Stem Cell 2008, 3:587-90.

50. Li W, Wei W, Zhu S, Zhu J, Shi Y, Lin T, Hao E, Hayek A, Deng H, Ding S: Generation of rat and human induced pluripotent stem cells by combining genetic reprogramming and chemical inhibitors. Cell Stem Cell 2009, 4:16-9.

5I. Liao J, Cui C, Chen S, Ren J, Chen J, Gao Y, Li H, Jia N, Cheng L, Xiao $\mathrm{H}$, Xiao L: Generation of induced pluripotent stem cell lines from adult rat cells. Cell Stem Cell 2009, 4: I I-5.

FI000 Factor 3.0 Recommended Evaluated by Zhu Chen 24 Feb 2009

52. Wu Z, Chen J, Ren J, Bao L, Liao J, Cui C, Rao L, Li H, Gu Y, Dai H, Zhu $H$, Teng $X$, Cheng L, Xiao L: Generation of pig-induced pluripotent stem cells with a drug-inducible system. J Mol Cell Biol 2009, I:46-54.

53. Ezashi T, Telugu BP, Alexenko AP, Sachdev S, Sinha S, Roberts RM: Derivation of induced pluripotent stem cells from pig somatic cells. Proc Natl Acad Sci U S A 2009, 106:10993-8.

54. Zhao XY, Li W, Lv Z, Liu L, Tong M, Hai T, Hao J, Guo CL, Ma QW, Wang $L$, Zeng $F$, Zhou Q: iPS cells produce viable mice through tetraploid complementation. Nature 2009, 46 I:86-90.

FI000 Factor 6.0 Must Read Evaluated by Insoo Hyun I5 Oct 2009

55. Boland MJ, Hazen JL, Nazor KL, Rodriguez AR, Gifford W, Martin G, Kupriyanov S, Baldwin KK: Adult mice generated from induced pluripotent stem cells. Nature 2009, 46I:9I-4.

56. Kang L, Wang J, Zhang Y, Kou Z, Gao S: iPS cells can support fullterm development of tetraploid blastocyst-complemented embryos. Cell Stem Cell 2009, 5:135-8.

57. Daley GQ, Lensch MW, Jaenisch R, Meissner A, Plath K, Yamanaka S: Broader implications of defining standards for the pluripotency of iPSCs. Cell Stem Cell 2009, 4:200-I; author reply 202.

58. Maherali N, Hochedlinger K: Guidelines and techniques for the generation of induced pluripotent stem cells. Cell Stem Cell 2008, 3:595-605.

FI000 Factor 6.0 Must Read Evaluated by Wolf Reik OI Apr 2009

59. Osafune K, Caron L, Borowiak M, Martinez RJ, Fitz-Gerald CS, Sato Y, Cowan CA, Chien KR, Melton DA: Marked differences in differentiation propensity among human embryonic stem cell lines. Nat Biotechnol 2008, 26:313-5.

60. Wilson KD, Venkatasubrahmanyam S, Jia F, Sun N, Butte AJ, Wu JC MicroRNA profiling of human-induced pluripotent stem cells. Stem Cells Dev 2009, I 8:749-58. 